\title{
Screening of Rhizosphere Bacteria from Rice Fields in The Coastal Area as Acc-Deaminase and Auxin Producer
}

\author{
Annisyia Zarina Putri ${ }^{\#}$, Djarot Sasongko", Dwi N. Susilowati* \\ \# Department of Biochemistry. Faculty of Mathematics And Natural Sciences, Bogor Agricultural University. Bogor, Indonesia \\ E-mail: annisyiaazp@gmail.com
}

*Microbial Division, Indonesia Center for Agricultural Biotechnology and Genetic Resources Research and Development (ICABIOGRAD), Jl. Tentara Pelajar 3A Bogor 16111, Indonesia

E-mail: d_nengsusi@yahoo.com

\begin{abstract}
Salinity and drought stress results in the production of ethylene. Rhizosphere bacterial activity suppresses the production of ethylene through the activity of 1-aminocycopropane-1-carboxylate (ACC) deaminase. In this study, a sampel of rhizosphere bacteria from coastal rice plant area was tested. The method used was acc deaminase activity test performed on Dworkin - Foster (DF) media and PCR acdS gene using specific primers of ACC and a quantitative analysis of the production of auxin (IAA). Of 47 isolates obtained, 8 were positively have acdS activity. The positive result was indicated by the presence of 1080 bp amplicon. Quantitative analysis showed the highest yield of $10.6 \mathrm{ppm}$ of auxin. The results prove that there are some bacteria originated from coastal rice plant area which have acc deaminase activity.
\end{abstract}

Keywords - ACC deaminase, auxin, drought, salinity, rhizosfere bacteria, rice

\section{INTRODUCTION}

Global warming has brought various impacts on environment. The sea level rises due either to the increasing of the volume of sea water as the result of the rising of the sea temperatures or the melting ice in the north and the south poles. Up to 2010, potential sea level rise varies from $60 \mathrm{~cm}$ to $100 \mathrm{~cm}$. Three main factors associated with global climate change that affects agricultural sector are : 1) changes in rainfall patterns ;2) increasing extreme climate events (floods and droughts); and 3) increasing air temperature and sea surface [1].

Rhizosphere is part of soil which is existed around plant roots and act as the outer defenses of plants against root pathogens. The population of microorganisms in the rhizosphere are usually more numerous and varied than on the ground instead of the rhizosphere [2].

According to Foster (1985) in [3]. Some rhizosphere microorganisms play an important role in nutrient cycling and soil formation processes, plant growth, affecting the activity of microorganisms as well as biological control against root pathogens. Rhizobacteria is a bacteria that lives in the root zone and colonize the root system of plants. Some bacteria are able to control the disease and plant growth promoters (Plant Growth Promoting Rhizobacteria) so it can be used as an inoculant biofertilizer [4]. Directly, PGPR (Plant Growth Promoting Rhizobacteria) stimulates plant growth by producing growth hormones, vitamins and various organic acids and increase nutrient intake for plants. Several types of rhizobacteria are currently developed as a biofertilizer agent, such as species of Pseudomonas, Bacillus, Streptomyces, Azospirillum, Agrobacterium, Rhizobium, Alkaligenes, Burkholderia, Beijerinkia.

The use of microbe controlling extreme environment stress such as salinity, particularly bacteria producing 1aminosiklopropona-1-carboxylate (ACC) deaminase (E.C.4.1.99.4) enzyme has never yet been reported. ACC deaminase is sitoplasm enzyme which is produced by some soil bachteria to degradade ACC prcusor of ethylene hormone on plants) to become amonia and $\alpha$-cetobutirate which are the source of Nitrogen and Carbone for bacteria [5]. Degradation of ACC by enzyme of ACC deaminase would then decrease ethylene in the plant and reduce the damage of the plant [6]. From the study of holticultures, wheat and nuts in research conducted in Canada, USA, India, dan Korea shows that the use of bacteria ACC deaminase could improve the freshness of the plants and improve the plants' resistence towards extreme enviromental stress and pattogenic attack [7].

The encoding genetic diversity of acdS of rice plants in coastal area has also not yet been reported. Thus, this 
reserach aimed to select some isolates of Rhizosphere bachteria in order to detect the variation of the acdS genes and to produce fitohormone auxin (indol-3-asetic acid). It was expected that the search of the potential of the isolates of these Rhizosphere bachteria could contribute to the agriculture along the coast land in anticipating the effect of the rise of the sea surface as the result of the climate change.

\section{MATERIAL AND METHODS}

\section{A. Material and Equipment}

Materials used for this research were 47 isolates of Rhizosphere taken from paddy field on the coast of Java island. The isolates are the collection of Research and Development Center for Biotechnology and Genetic Resources (BB-BIOGEN) Bogor-Indonesia. Other materials are PCR components: GoTaq DNA polimerase, loading dye $6 \mathrm{x}$, nuclease free water, aquades, marker $1 \mathrm{~kb}$, DNA isolation kit, wizard DNA genom purification kit. Primer asds, agarose, buffer TAE, clonning kitt. Equipment used are PCR machine, incubator, fridge, microwave, Air Flow lamina,autoclave, waterbath, shacker, centrifuse, electroforesys agarosa, UV-Translluminator, and other equipment which are commonly used in a laboratory.

\section{B. Research Methodology}

\section{1) Rejuvenate and puriry of bacteria isolates [8].}

Rejuvenation and purification of bacterial isolates were done by preparing 1 ose colonies of bacteria taken from a stock culture and grown at SEA media (soil extract agar) with a solid streak method then incubated at room temperature for 7 days. Isolation of DNA. Isolation of bacterial genomic DNA is done by using the Promega Wizard genomic DNA purification KIT. Bacterial culture that had been grown in LB medium was placed to a micro tube about $1.5 \mathrm{~mL}$, and then centrifuged for 2 minutes at a speed of $14000 \mathrm{rpm}$. Pellets that were formed were taken and the supernatant were discarded. To the pellet isolates with gram -negative bacteria cell lysis process was directly done meanwhile to the pellets with gram-positive bacteria resuspension with $50 \mathrm{mM}$ EDTA as $480 \mu \mathrm{l}$ was done prior to a cell lysis process. Then, $120 \mathrm{~mL}$ lysozyme was added to the pellets before they were incubated at $37^{\circ} \mathrm{C}$ for 45 minutes. The samples were again centrifuged at a speed of $14000 \mathrm{rpm}$ for 2 minutes. The pellet formed were taken and the supernatant was discarded. The next stage was a bacterial cell lysis which was done by adding $600 \mathrm{~mL}$ nuclei lysis solution to the sample which was then incubated at $80^{\circ} \mathrm{C}$ for 5 minutes. About $3 \mathrm{~mL}$ RNase was added into the sample and incubated at $37^{\circ} \mathrm{C}$ for 45 minutes.

\section{2) Auxin Production Test.}

Quantitative analysis of AIA was done using method by Gupta et al. [9].

3) Genetic Amplification of acdS.

Amplification was done using two primeries, they are DegACCf primary

$\left(5^{\prime}-\right.$ GGBGGVAAYAARMYVMGSAAGCTYGA-3') and DegACCr primery (5'TTDCCHYKRTANACBGGRTC-3'). PCR used was $25 \mu 1$.

\section{4) Genetic Amplification Amplifikasi of $16 \mathrm{~S}$ rRNA.}

16S rRNA was amplified by PCR method using primary 63F (5'CAGGCCTAACACATGCAAGTC'3) dan 1387R (5'GGGCGGWGTGTACAAGGC'3).

\section{5) Genetic Sequensing of $16 \mathrm{~S}$ rRNA.}

\section{RESULT}

\section{A. Activity acdS at DF Media}

The results of examination of ACC deaminase activity is presented in Figure 1. The isolates were grown on three medias: media (1), DF (Dworkin-Foster), as negative control, which is shown by the absent of the bacteria; media (2) DF + AS (amonium sulphate), as positive control which is shown by the presence of isolate and media (3), DF + ACC (C), for isolates which can grow. This becomes an indication for the existence of enzim of ACC deaminase which is shown by the presence of a thick white circle. There were 4 isolates that have ACC deaminase activity.
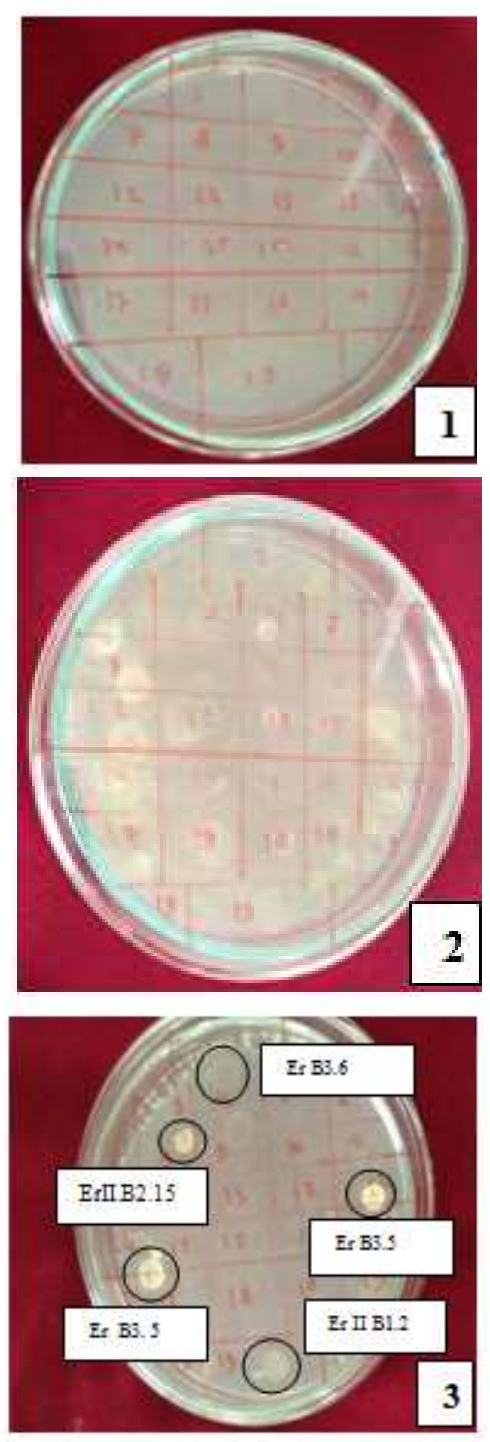

Fig. 1. ACC Deaminase Test Result

Remark : $1: \mathrm{DF}, 2: \mathrm{DF}+$ amonium sulphate , 3:DF + ACC 


\section{B. Auxin Production}

The auxin content which is produced by the isolate Rhizosphere taken from paddy field ranges from 3.6 to 10.6 ppm. Meanwhile the result of the analysis of auxin production presented in Table 1 shows that the highest activity wis $10.6 \mathrm{ppm}$

TABLE I

QUANTITATIVE ANALysis RESUlt of ACTIVITIES OF AIA

\begin{tabular}{|l|c|c|}
\hline \multicolumn{1}{|c|}{ Isolate } & $A c d S$ & AIA production (ppm) \\
\hline Er II B2.5 & + & 3.6 \\
\hline Er I B1.8 & + & 47.3 \\
\hline Er I B3.6 & + & 4.1 \\
\hline Er II B2.13 & + & 10.6 \\
\hline Er II B2.10 & + & 2.3 \\
\hline Er II B2.4 & + & 10.35 \\
\hline Er II B2.15 & + & 3.4 \\
\hline Er II B1.2 & + & 6.05 \\
\hline
\end{tabular}

The results of colorimetry test using spectrophotometer reveals that all bachteria on the supernatan culture tested produces AIA hormone with diferent concentration. Differences in the AIA production might be due to different species and strains tested, condition of the culture, the growth phase and the availability of the substract [10]. Other factors that might result in the differences are genetic structure, growth speed, enzime activity and its ability to converse triptophan contained in AIA, and the length of time of incubating the culture [10].

\section{Amplificon of PCR gen acdS}

Detection of the existence of ACC Deaminase gen can be done by using polymerase chain reaction (PCR). Of 47 samples tested, 8 is apparantly positive. They are Er II B2, Er II B2. 13, Er B1 8, Er II B2. 10, Er II B2. 4, Er B3. 6, Er II B1. 2 dan Er II B2. 15. The positive result was indicated by 1080 bp DNA with ACCf and ACCr specific primery. The production of ACC deamninase is very efficient and important for endofit to stimulate the host plant..

The Gen acdS in this research was obtained on 1080 bp amplicon. This is similar with the result obtained by Yan Jun Jia et al.[11]. from a Rhizosphere bactheria, Pseudonomas sp. According to Jin Duan et al [12] of 27 isolates amplified with PCR using specific primery for ACC, 17 are ACC deminease positive. This is marked by the existence of DNA ribbon on amplicon 1020 bp. The result of Jin Duan's research apparantely different from that of this present research which is on $1080 \mathrm{bp}$.

Subrahmanyam [13] reports that agrosa, soil bacteria in India, which is tested with ACC specific primery shows a result on ACC positive on $1080 \mathrm{bp}$ amplicon after being PCR. The result of research by Mattos et al. [14] proves that endofit bacteria has capability to improve the number of lateral roots and rambut akars of paddy plants. The purpose of the amplication of acdS gen is to amplificate the gen which positively bring gen with fragment of $1080 \mathrm{bp}$. The amplification of PCR with gen acdS specific primery indicates 8 positive isolates.

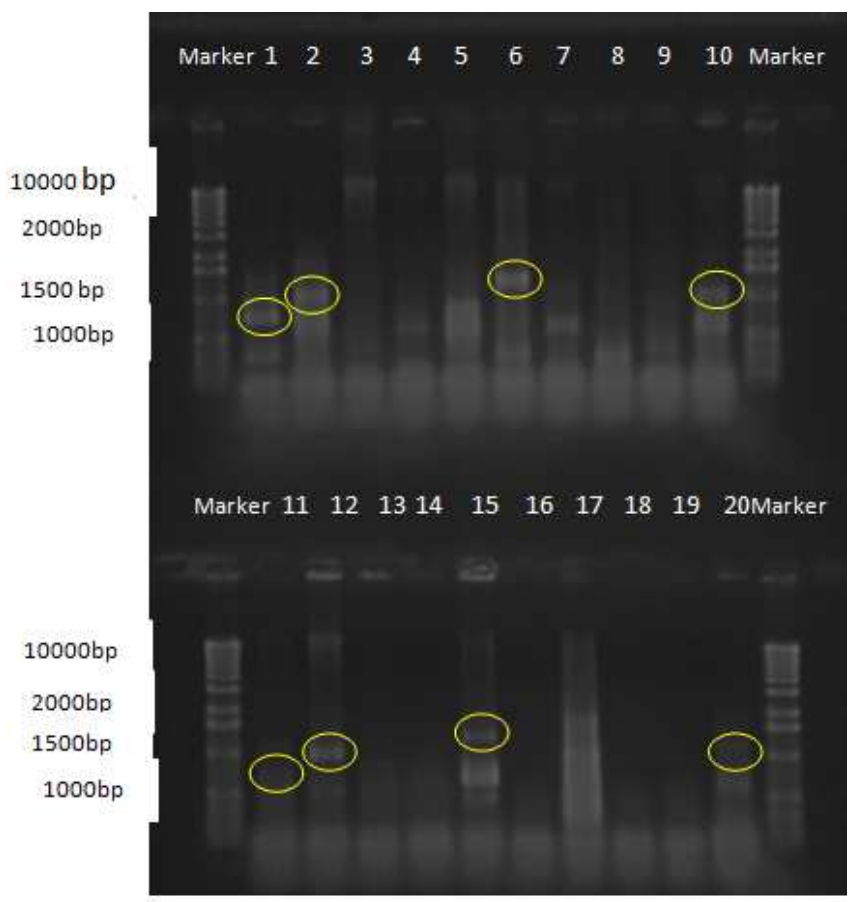

Figure 2 The Amplicon of PCR gen acdS with 1080 bp size

Notes: Marker: 1 kb, 1= Er II B2 5, 2= Er B1 8, 3= Er B2 2, 4= Er II B2 12, $5=$ Er II B1 1 6= Er B3 6 7= Er II B3 10 8= Er B2 3, 9= Er B1 7 10=Er II B2 13, 11= Er II B2 10, 12= Er II B2 4, 13= Er B3 10 14= Er II B3 10 15= Er II B2 15 16= Er B2 13 17=Er B2 1 18= Er B2 6 19=Er B3 1 20=Er II B1 2

At the last step, species indentification of bachteria which is closer to the superior sampel data taken from the GeneBank is done. The identification used blast N program taken drom NCBI (National Center for Biotechnology Information) site. After the data was obtained, the genetic tree is made using Mega 5 program in order to get a closest familyy relation between the suprior sample with the data from the Gene Bank. The amplification of the 16 rDNA test shows positive result (Figure 3 ). The result of figonetic analysis can be seen in Table 2 . The blast result shows that the family relation was possessed by sampels: ErII B2.13 (Bacillus safensis) dan ErII B1.2 (Bacillus Pumilus).

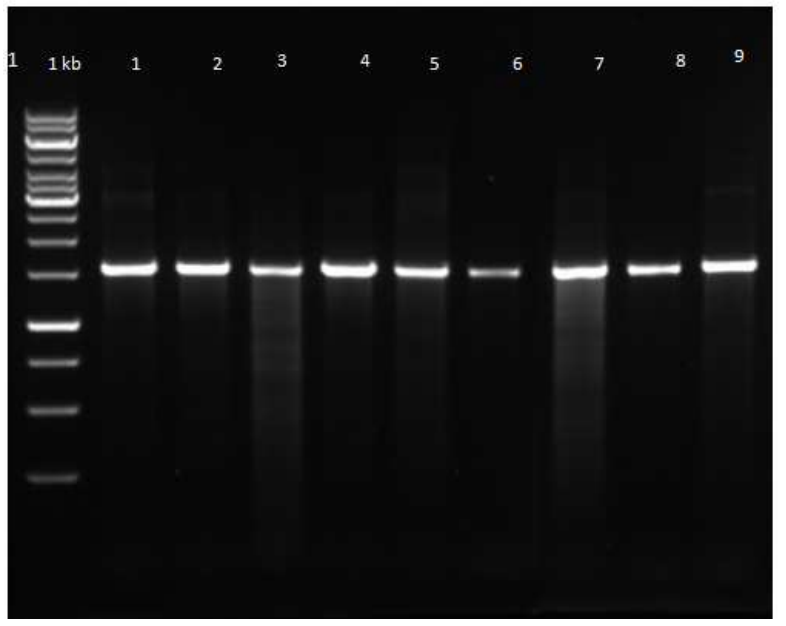

Figure 3 Product of DNA PCR 16S RNA 
TABLE II

SEQUENCING ANALYSIS RESULT OF DNA SAMPLE USING BLAST N PROGRAM

\begin{tabular}{|c|c|c|c|}
\hline Isolate & Sequence of homolog bacteria & $\begin{array}{c}\% \\
\text { identity }\end{array}$ & Acsess No. \\
\hline Er IIB2. 13 & $\begin{array}{l}\text { Bacillus safensis } \\
\text { gene for } 16 \mathrm{~S} \text { ribosomal RNA, } \\
\text { partial sequence }\end{array}$ & $99 \%$ & FO-036b. \\
\hline Er II B2. 4 & $\begin{array}{l}\text { Bacillusaerophilus strain } \\
\text { KUDC1727 16S ribosomal RNA } \\
\text { gene, partial sequence }\end{array}$ & $98 \%$ & KC414706 \\
\hline Er II B1.2 & $\begin{array}{l}\text { Bacillus_pumilus isolatee FM10 } \\
\text { 16S ribosomal RNA gene, partial } \\
\text { sequence }\end{array}$ & $99 \%$ & $\underline{\text { DQ289077.1 }}$ \\
\hline Er II B2.5 & $\begin{array}{l}\text { Microbacterium arborescens. } \\
\text { IARI-KPI 16S ribosomal RNA } \\
\text { gene, partial sequence }\end{array}$ & $99 \%$ & KF712889.1 \\
\hline $\begin{array}{l}\text { ER I B1. } 8 \\
\text { Er I B3.6 }\end{array}$ & $\begin{array}{l}\text { Bacillus amyloliquefaciens strain } \\
\text { YCG37 16S ribosomal RNA } \\
\text { gene, partial sequence } \\
\text { Stenotrophomonas maltophilia1 } \\
\text { 16S ribosomal RNA gene, partial } \\
\text { sequence }\end{array}$ & $\begin{array}{l}98 \% \\
90 \%\end{array}$ & JF775416.1 \\
\hline
\end{tabular}
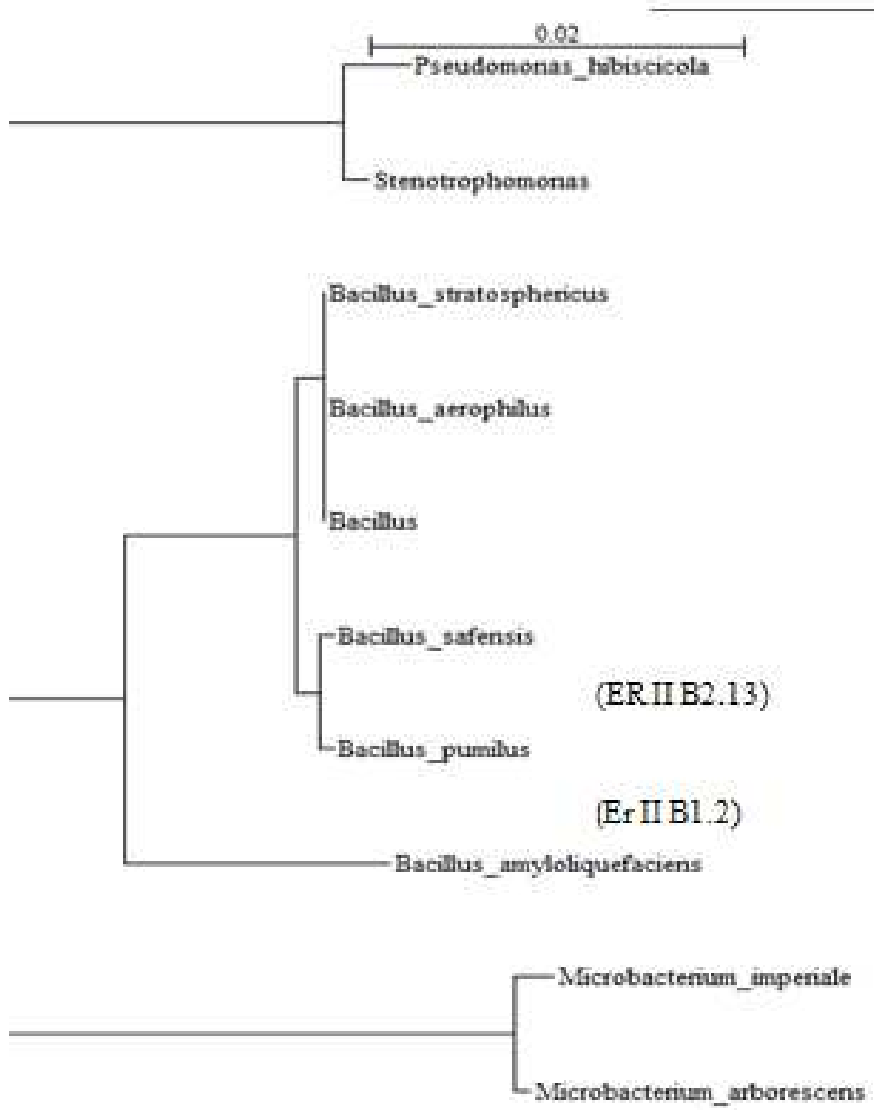

Fig 4. Phylogenetic tree of superior sample and GeneBank data using Neighbor Joining (NJ) with bootstrap 100x

\section{CONCLUSIONS}

The result of the research reveals that 8 of 47 isolates of rhizosphere bacteria contains amplikon with $1080 \mathrm{bp}$ and specific primary ACCf and ACCr. The bachteria produces auxin (AIA) with $3,5 \mathrm{ppm}$ to $10.6 \mathrm{ppm}$ concentration. The ACC deeaminase activity test done on DF media shows a positive result of Er B3.5 and Er II B2.5. Blast result reveals that the closest family relationship was shown by ErII B2.13 (Bacillus safensis) dengan ErII B1.2 (Bacillus pumilus). Further research to inoculate plant in a direct way needs to be done to observe the effect of ACC deaminase gen resulted by the isolates of superior bachteria towards the growth of plants. In addition, patogonity test to superior bachteria is also needed.

\section{ACKNOWLEDGMENT}

The writer expresses her deep gratitude to Prof. Yoshiyuki Niimi, Prof. Tsutomu Morinaga and Prof. Takashi Oku from Prefectural University of Hiroshima-Japan for all facilities provided to conduct a part of this research in their labs and for their kind help and guidance in doing the research.

\section{REFERENCES}

[1] Salinger MJ Salinger MJ. 2005. Climate variability and change: past present, and future over view. Climate Change

[2] Carlile MJ, Watkinson SC, Goodday GW. 2001. The Fungi. 2nd NewYork, London : Academic Press

[3] Hornbyn D. 1990. Root diseases. In Lynch JM, editor. The Rhizosphere. New York: John Willey \& Sons.

[4] Kennedy IR, ATMA. Choudhury, ML. Kecskes. 2004. Nonsymbiotic bacterial diazotrophs in crop-farming systems: can their potential for plant growth promo-tion be better exploited. Soil Biol. Biochem. 36(8): 1229-1244.

[5] Jacobson CB, JJ Pasternak, BR Glick. 1994. Partial purification and characterization of ACC deaminase from the plant growth promoting rhizobacterium Pseudomonas putida GR12-2. Can. J. Microbiol. 40: $1019-1022$

[6] Grichko VP, Glick BR. 2001. Amelioration of flooding stress by ACC deaminase-containing plant growth promoting bacteria. Plant Physiol. Biochem 39: 11-17.

[7] Glick BR, B Todorovic, J Czarny, Z Cheng, J Duan. 2007. Promotion of plant growth by bacterial ACC deaminase. Crit. Rev. Plant Sci. 26: $227-242$

[8] Ding Y, Wang J, Liu Y, Chen S. 2005. Isolation and identification of nitrogen-fixing bacilli from plant rhizospheres in Beijing region. J Appl Microbiol 2005;99:1271-81.

[9] Gupta M, Shashi K, Arvind G, Bikram S, Rupinder T.2012. Isolation and identification of phosphate solubilizing bacteria eble to enhance the growth and aloin-A biosynthesis of Aloe barbadensis Miller. Microbiological Research 167: 358-363.

[10] Khalid, M., M. Arshad. S. A. Abbas., 2001. Substrate Dependent Microbially Derived Plant Hormones For Improving Growth Of Maize Seedlings. Pakistan Journal of Biological Science. 3(2): 289291

[11] Jia Y-J, $\mathrm{H}$ Ito , $\mathrm{H}$ Matsui \& $\mathrm{M}$ Honma. 2000. 1Aminocyclopropane-1-carboxylate (ACC) Deaminase Induced by ACC Synthesized and Accumulated in Penicillium citrinum Intracellular Spaces. Bioscience, Biotechnology,nd Biochemistry 64 (2): 299-305

[12] Duan J, KM Muller, TC Charles, S Vesely, BR Glick. 2009. 1 Aminocyclopropane-1-Carboxylate (ACC) Deaminase Genes in Rhizobia from Southern Saskatchewan. Microbial Ecology 57 (3): 423-436.

[13] Subrahmanyam G. Ju-Pei Shen,Yu-Rong Liu, Gi Archana, Ji-Zheng He. 2013. Response of ammonia-oxidizing archaea and bacteria to long-term industrial effluent-polluted soils, Gujarat, Western India. Environmental Monitoring and Assessment. 186 (7): $4037-$ 4050

[14] Mattos KA, Pádua VLM, Romeiro A, Hallack LF , Neves BC, Ulisses TMU,Barros CF, Todeschini1 AR, Previato JO , Mendonça Previato L. 2008.. Endophytic Colonization of Rice (Oryza sativa L) by the Diazotrophic Bacterium Burkholderia kururiensis and Its Ability to Enhance Plant Growth. Anais da Academia Brasileira de Ciências 80(3): 477-493 